\title{
PHYTOCHEMICAL STUDIES AND PHARMACOGNOSTICAL EVALUATION OF ZINGIBER CASSUMUNAR ROXB
}

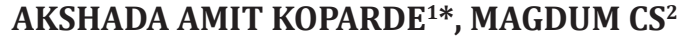 \\ ${ }^{1}$ Department of Pharmaceutical Chemistry, Krishna Institute of Pharmacy, Karad - 415 110, Maharashtra, India. ${ }^{2}$ Department of , \\ Rajarambapu College of Pharmacy, Kasegaon, Sangli, Maharashtra, India . Email: akshadakakade@yahoo.com
}

Received: 15 May 2017, Revised and Accepted: 16 June 2017

\section{ABSTRACT}

Objective: Zingiber Cassumunar Roxb is a well known medicinal plant employed to cure various diseases were reported to possess good medicinal value in traditional system of medicine. The present investigation deals with microscopic, macroscopic and preliminary phytochemical investigation of rhizome to give clear standards for identification of the drug.

Method: For the microscopic evaluation, the powder was soaked in a solution of $20 \%$ chloral hydrate and then mounted on a glass slide with the help of glycerine. The mounted slides were then observed under a photographic microscope. Microscopic sections were cut by free hand sectioning.

Result: The research paper study revealed that the yellow colour inside the rhizome is the main characteristic feature. The presence of central cylinder region containing yellow coloured oleo-resin and oil cells in cortex are the main characteristic feature. The presence irregularly rounded, ovoid starch grains and oil globulues situtated inside the parenchyma are the distinguishing features and can be used as anatomical markers. Rhizome powder showed some of the characteristic features such as starch grains with a rounded shape situated at narrow end and parenchymatous cells with characteristically wrinkled wall, air spaces. Cork, cortex, cork cells, and floem fibres also shows pharmacognostical characteristics of $Z$. cassumunar Roxb. Preliminary phytochemical analysis of the rhizomes revealed the presence of glycosides, sterols, triterpenes, saponins, tannins, flavonoids, amino acids and volatile oils.

Conclusion:The present study signifies the use of TLC (Thin layer chromatography) profiles for determining the identity of active chemical constituents.

Keywords: Zingiber cassumunar Roxb, Indigenous medicines, Oil globulues, Pharmacognostical characteristics, Thin layer chromatographic.

(C) 2017 The Authors. Published by Innovare Academic Sciences Pvt Ltd. This is an open access article under the CC BY license (http://creativecommons. org/licenses/by/4. 0/) DOI: http://dx.doi.org/10.22159/ajpcr.2017.v10i10.20004

\section{INTRODUCTION}

India has heritage of traditional medicine, Materia medica of India provides a lot of information on the folklore practices and traditional aspects of therapeutically important natural products. The evaluation of these drugs is mostly based on phytochemical, pharmacological, and allied approaches including various instrumental techniques such as chromatography, microscopy, and others [1]. The herbal medicine is based on traditional medicine, exists in every continent of the globe and in every cultural area of the world. Each of these traditional medicines has its own origin and an individual basic philosophy [2]. Exploration of the chemical constituents of the plants and pharmacological screening may provide us the basis for developing a lead molecule. Herbs have provided us some of the very important life-saving drugs used in the armamentarium of modern medicine.

\section{About Zingiber cassumunar Roxb.}

Zingiber cassumunar Roxb. (family: Zingiberaceae), known locally as "Phlai" in Thai, is a perennial herb, consisting of underground rhizomes. Conventionally, the rhizome of this plant has been used for treatment of inflammation, muscle and joint problems, menstrual disorders, abscesses, and skin diseases and wound healing the ethnomedical use of Z. cassumunar Roxb. (Zingiberaceae) and its frequently reported uses of the rhizome include topical treatment of sprains, contusions, abscesses, and skin diseases. The rhizome can be crushed and directly rubbed onto the afflicted area or the sliced rhizome can be fried in a pan together with coconut oil, to obtain a composite oil, which is applied to the inflamed area [3]. The findings support the use in Thai traditional medicine of Zingiberaceous plants, especially Z. cassumunar, for treatment of allergy and allergic-related diseases [4].
Phytochemical investigations of $Z$. cassumunar rhizomes have revealed the presence of phenylbutanoids, cyclohexene derivatives, naphthoquinones, vanillin, vanillic acid, veratric acid, terpenoids, $\beta$-sitosterol, and curcuminoids.

In combination with other medicinal plants, Z. cassumunar was found to be effective in relieving asthmatic symptoms in children and adults. Several isolated compounds have been found to possess anti-inflammatory activity, for example, two phenylbutanoids [5]. (E)-4-(3_,4_-dimethoxyphenyl)but-3-enyl acetate and (E)-4-(3_4_dimethoxyphenyl)but-1,3-diene.

Ginger has been used as a spice and as natural additives for more than 2000 years [6]. Furthermore, ginger has many medicinal properties. Studies have shown that the long-term dietary intake of ginger has hypoglycemic and hypolipidemic effect [7]. Ginger has been identified as an herbal medicinal product with pharmacological effect. Ginger suppresses prostaglandin synthesis through inhibition of cyclooxygenase - 1 and cyclooxygenase - 2 . In traditional Chinese and Indian medicine, ginger has been used to treat a wide range of ailments including stomach aches, diarrhea, nausea, asthma, and respiratory disorders [8]. Ginger is widely used because it contains good medicinal properties.

Other Zingiber zerumbet (L.) Sm. (family: Zingiberaceae) have revealed the isolation of flavonoids, sesquiterpenes, and aromatic compounds. The volatile oil of the rhizome contains zerumbone, humulene, camprene $\alpha$-caryophyllene, and camphene. The rhizomes of this plant are used as an anti-inflammatory agent in traditional medicine. A monocyclic sesquiterpene, zerumbone ( $2 E, 6 E, 10 E$-humulatrien-1-one), which 
was found as a major component of the essential oil of Z. zerumbet, has been studied intensively for potential use in anti-inflammatory, chemopreventive, and chemotherapeutic strategies. Extracts of the rhizomes are known to have anti-inflammatory, chemopreventive, and chemotherapy applications and are anti-HIV, antitumor, cytotoxic, and antibacterial agents [9].

Thus, Z. cassumunar Roxb. also finds prominent importance not only in Ayurvedic medicine butalso in modern medicine. However, the extensive pharmacognostic studies and thin-layer chromatographic (TLC) analysis have not been established properly. Therefore, the current study has been undertaken to carry out the detailed pharmacognostic and phytochemical studies for this species, which will be helpful for the proper identification and development of standardization protocols of commercial samples.

\section{MATERIAL AND METHODS}

\section{Plant material}

Z. cassumunar Roxb. [10] Plant species along with leaves, flowers, roots, and rhizomes were collected from the Bhimashankar region. Then, this plant was identified and authenticated by Dr. G. G. Podar, HOD, Department of Botany, Y. C. College of Science, Karad and Voucher specimen was deposited at the same college as number AAK2.

\section{Processing of plant material}

After collection, rhizomes were washed thoroughly and were separated from other parts, cleaned and dried for further use.

\section{Macroscopic examination}

The detail macroscopic characters of fresh rhizomes were noted including special features such as color, odor, shape, and size [6].

\section{Microscopic examination}

For the microscopic evaluation, the powder was soaked in a solution of $20 \%$ chloral hydrate and then mounted on a glass slide with the help of glycerine. The mounted slides were then observed under a photographic microscope [11]. Microscopic sections were cut by free hand sectioning. Numerous temporary and permanent mounts of the microscopical sections of the rhizomes were made and examined microscopically. Histochemical reactions were observed with different staining agent for the general and specific microscopic characteristic of tubers. Photomicrographs of the microscopical sections were taken with the help of motic microscope $[12,13]$.

\section{Powder characteristics}

Preliminary examination like behavior of powder with different chemical reagents and microscopically examination was carried out according to the method given in Khandelwal and Kokate $[6,13]$.

\section{Fluorescence analysis of tuber powder}

Powder material was analyzed under visible light, short UV light $(254 \mathrm{~nm})$ after treatment with various organic/inorganic solvents/ reagents such as petroleum ether, methanol, water, $10 \%$ aqueous $\mathrm{NaOH}, 50 \% \mathrm{HCl}, 50 \% \mathrm{H}_{2} \mathrm{SO}_{4}$, acetic acid, $50 \% \mathrm{HNO}_{3}$, etc. [14].

\section{Physicochemical parameters}

Physicochemical parameters, such as percentage of total ash, extractive values and moisture content loss on drying (LOD), and swelling index, were determined as per official method of the Indian pharmacopoeia and the WHO guidelines on the quality control methods of medicinal plant materials $[15,16]$.

\section{Extraction and preliminary phytochemical screening}

Extraction forms the first basic step in medicinal plant research because the preparation of crude extracts from plants is the starting point for the isolation and purification of chemical constituents present in plants [17].

Powdered drug was extracted with n-hexane, dichloroform, chloroform, acetone, ethanol, and water successively by soxhlet extraction and microwave. Microwave extraction can be the better alternative to conventional extraction.

The extracts were dried and weighed. The presence or absence of different phytoconstituents, namely, triterpenoid, steroids, alkaloids, vitamins, tannins, glycosides and flavonoids, etc., were detected by usual given method [6].

\section{Thin-layer chromatographic studies}

TLC studies [18] of dichloromethane extract of $Z$. cassumunar Roxb. were studied. It was carried out on aluminum plates precoated with silica gel F254 of $0.2 \mathrm{~mm}$ thickness and mobile phase was developed with trial and error basis. Finalized mobile phase for dichloromethane extract was chloroform:dichloromethane (5.4:11.2) and for alcoholic extract toluene:ethyl acetate:methanol:formic acid (6:6:0.4:1.6). Plate was observed in visible light and it was also sprayed with anisaldehyde sulfuric acid spray reagent followed by heating the plate at $110^{\circ} \mathrm{C}$. The color and Rf value of resolved spots were noted.

\section{RESULTS}

\section{Macroscopic characters}

Green color leaves are present at the nodal region with 5-8 $\mathrm{cm}$ long rhizomes are $10-14 \mathrm{~cm}$ long and $2.5 \mathrm{~cm}$ broad, branched irregularly with node and internodes. White flowers are developed $30 \mathrm{~cm}$ above the ground part. The outer surface of the rhizome is smooth and light grey, internally dark yellow which is the identification characteristic of Z. cassumunar Roxb. These are hard and brittle at outer region, easily

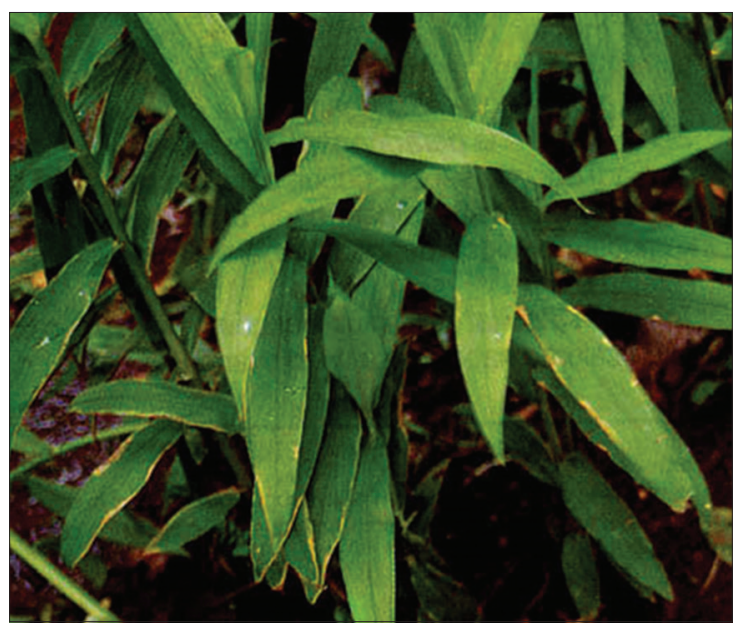

Fig. 1: Green leaves

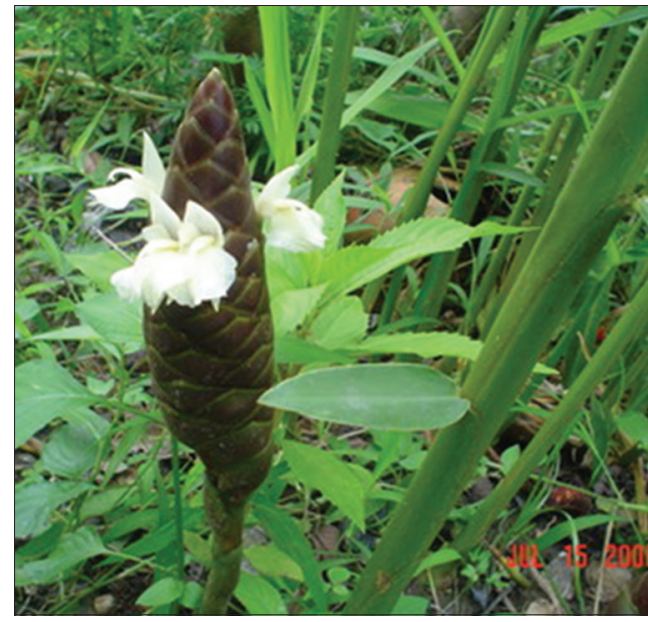

Fig. 2: White flowers 


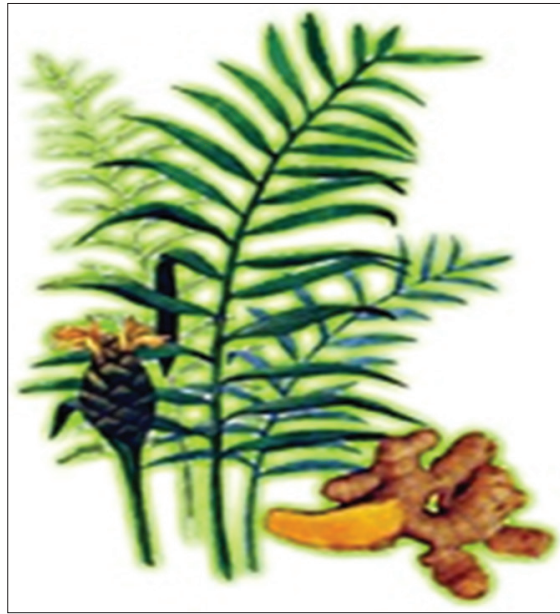

Fig. 3: Whole plant

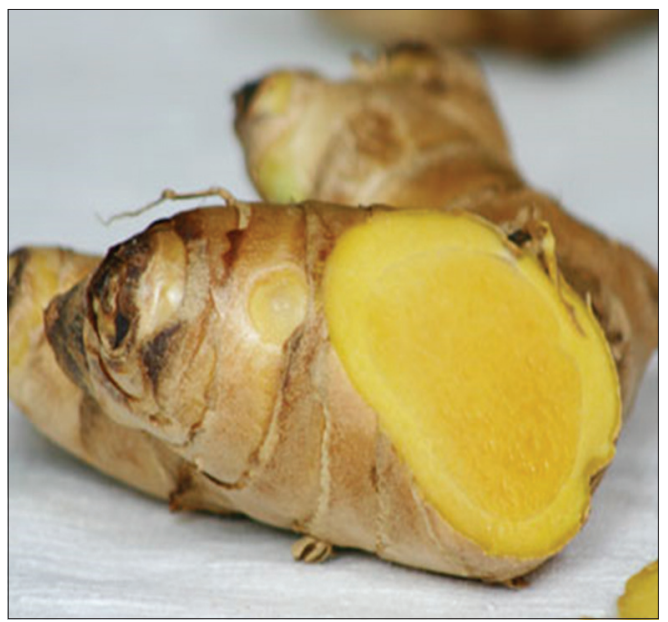

Fig. 4: Rhizomes with dark yellow inside

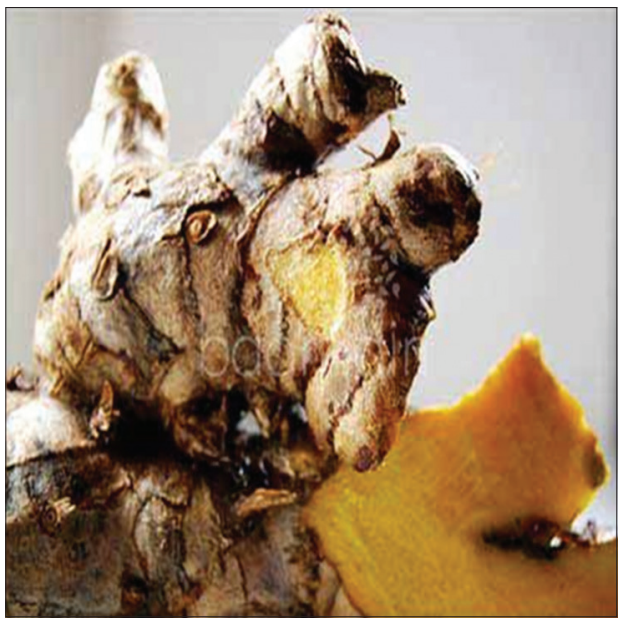

Fig. 5: Rhizomes with dark yellow inside

breaking, fragrant odor, aromatic, and slightly bitter-sweet in taste (Fig. 1-6).

\section{Microscopic characters}

Transverse section of the rhizome showed outer single layered epidermis having rectangular and elongated cells and it is followed by thin-walled cork cells of 6-10 layers, irregularly elongated. The rhizome

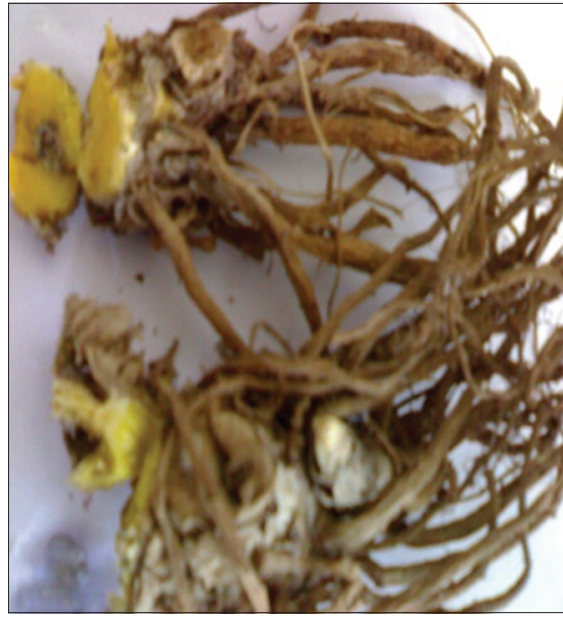

Fig. 6: Rhizomes with dark yellow inside

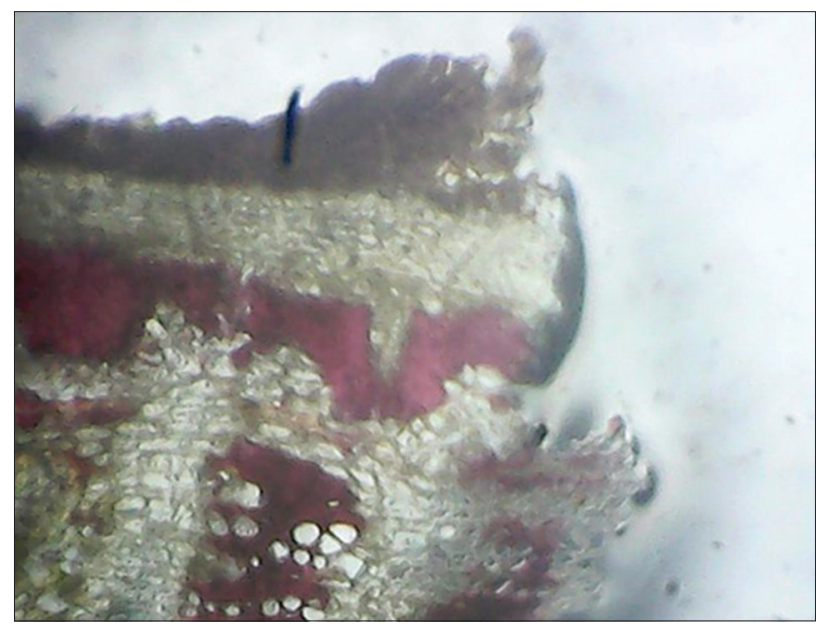

Fig. 7: Transverse section

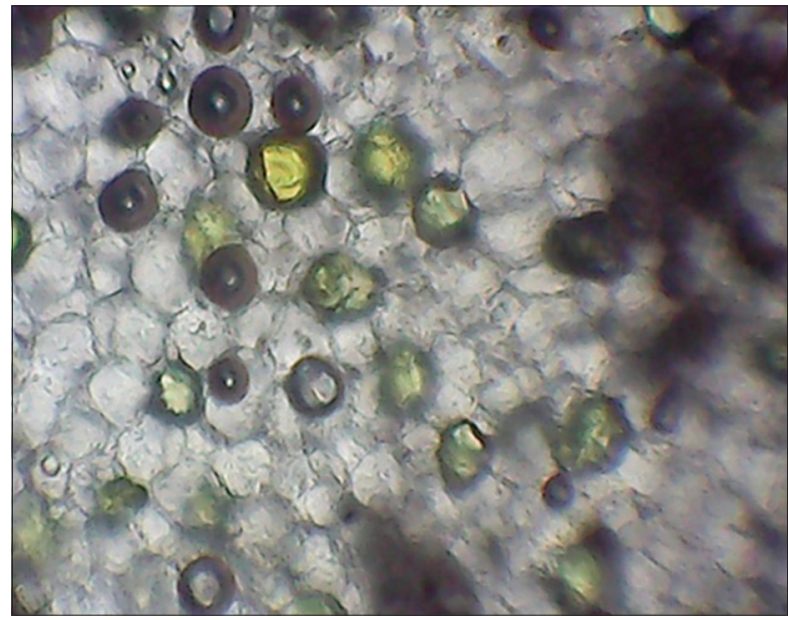

Fig. 8: Parenchyma with yellow color oil globules

showed cork cells, cortex, and collateral vascular bundle. Cortex consists of several layers of parenchymatous cells with intercellular air spaces and contains starch. Oil cells are present in cortex as well as parenchyma cells. Yellow colored oleoresin is present at central cylinder region. Closed, collateral vascular bundles are found in a circle in the region just inside the epidermis. The starch grains are abundant in cortex with ovoid irregular shape (Figs. 7-10). 
Powder characteristics

Macroscopic and microscopic

The rhizome powder is light brown, slightly rough in touch with slight aromatic odor. Pressing a little amount of powder between filter paper, greasy stain was found, indicating presence of oil cells. Starch grains were present when stained with iodine solution. Microscopical examination the powder showed cork cells, isolated fibers, yellow colored oil globules, pholem fiber surrounded with cork cells, and parencymatoues cells. Behavior of powder with different chemical reagents is shown in Table 1. The fluorescence

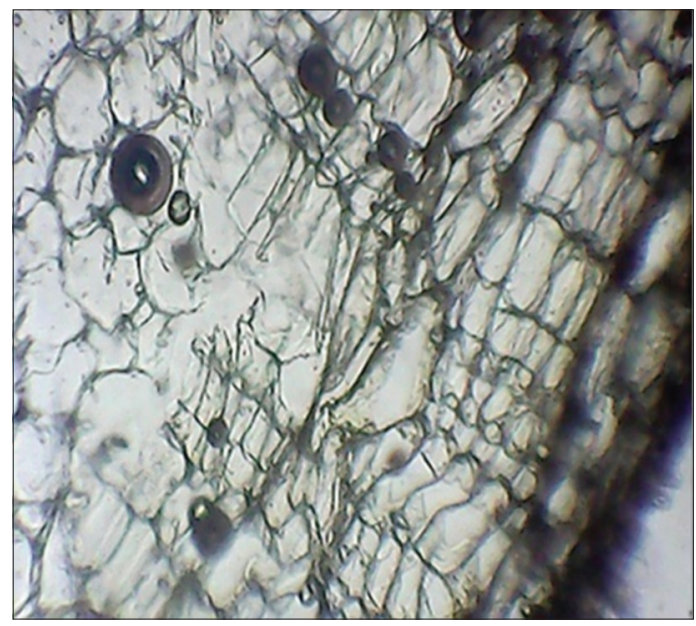

Fig. 9: Cork, cortex parenchyma with air spaces

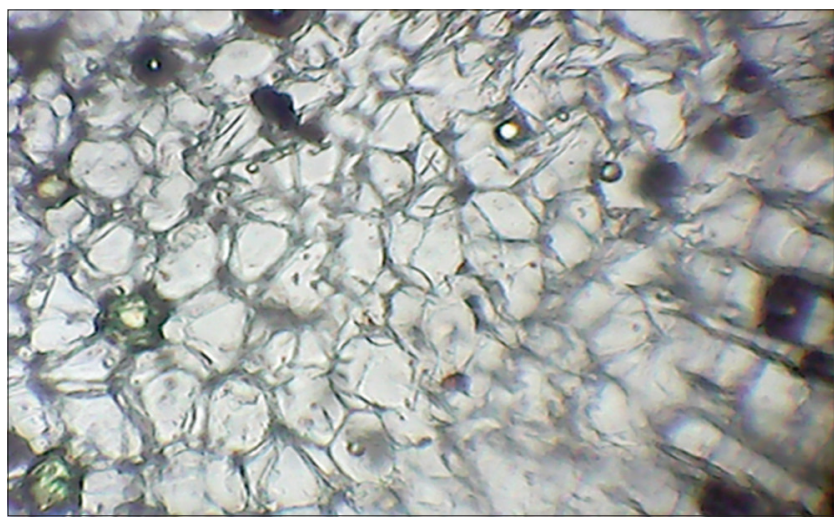

Fig. 10: Parenchyma cells

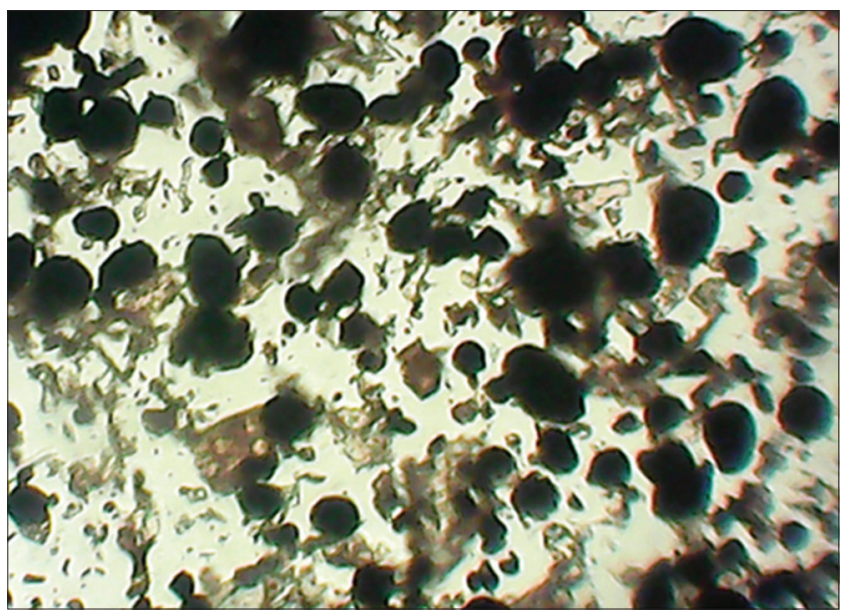

Fig. 11: Starch granules
Table 1: Behavior of Zingiber cassumunar Roxb. rhizome powder with different chemical reagent

\begin{tabular}{|c|c|c|}
\hline Reagent & $\begin{array}{l}\text { Color/ } \\
\text { precipitate }\end{array}$ & Constituent \\
\hline Concentrated sulfuric acid & Reddish & Steroid present \\
\hline Picric acid solution & No yellow ppt & Alkaloid absent \\
\hline $\begin{array}{l}\text { Aqueous silver nitrate } \\
\text { solution }\end{array}$ & No ppt & Protein absent \\
\hline Aqueous ferric chloride (5\%) & Black color & Tannin present \\
\hline $\begin{array}{l}\text { Aqueous mercuric chloride } \\
\text { solution }\end{array}$ & $\begin{array}{l}\text { No brown } \\
\text { color }\end{array}$ & Alkaloid absent \\
\hline Ammonical solution & No change & $\begin{array}{l}\text { Anthraquinone } \\
\text { glycoside absent }\end{array}$ \\
\hline Iodine solution & Blue & Starch present \\
\hline Ruthenium red & No red color & Mucilage absent \\
\hline Magnesium-HCl & No change & Flavonoid present \\
\hline
\end{tabular}

Table 2: Fluorescence analysis of powdered rhizome Zingiber cassumunar Roxb.

\begin{tabular}{lll}
\hline Treatment & Visible light & Short UV (254 nm) \\
\hline Powder as such & Light brown & Brown \\
Powder + 10\% NaOH & Green & Light green \\
Powder + ammonia & Greenish brown & Light brown \\
Powder + acetic acid & Yellowish green & Green \\
Powder + $\mathrm{HNO}_{3}$ & Light yellow & Yellowish green \\
Powder $+50 \% \mathrm{HCl}$ & Green & Slight brown turbid \\
Powder + iodine light & Yellow & Light green \\
green & & \\
Powder $+\mathrm{FeCl}_{3}$ & Dark green & Dark green \\
\hline
\end{tabular}

UV: Ultra violet

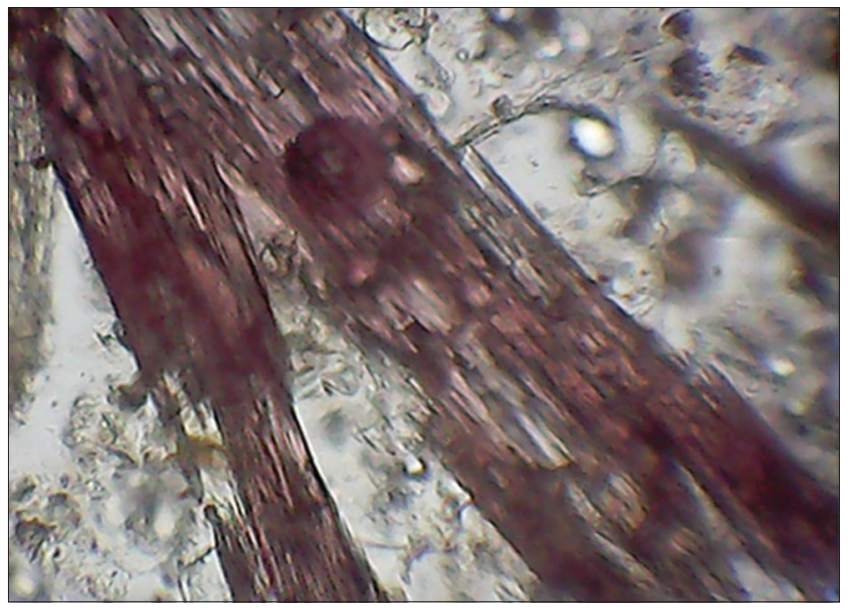

Fig. 12: Phloem fiber (closed view)

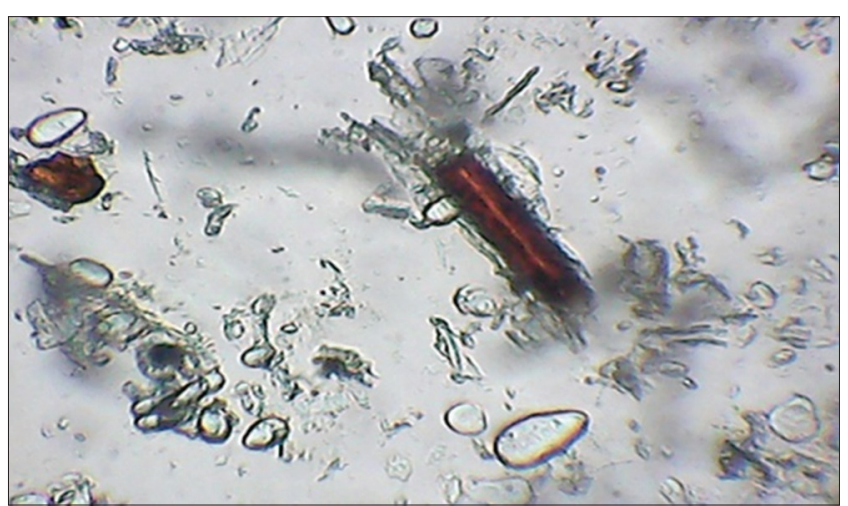

Fig. 13: Phloem fiber 
Table 3: Preliminary phytochemical investigation of rhizome extracts

\begin{tabular}{|c|c|c|c|c|c|c|}
\hline Test & $\begin{array}{l}\text { Aqueous } \\
\text { extract }\end{array}$ & $\begin{array}{l}\text { Hexane } \\
\text { extract }\end{array}$ & $\begin{array}{l}\text { DCM } \\
\text { extract }\end{array}$ & $\begin{array}{l}\text { Chloroform } \\
\text { extract }\end{array}$ & $\begin{array}{l}\text { Acetone } \\
\text { extract }\end{array}$ & $\begin{array}{l}\text { Ethanol } \\
\text { extract }\end{array}$ \\
\hline Test for carbohydrates & + & + & + & - & - & - \\
\hline Test for proteins & - & + & + & - & - & - \\
\hline Test for alkaloids & + & + & + & + & - & - \\
\hline Test for glycosides & + & - & - & - & - & - \\
\hline Test for saponins & & - & - & + & - & - \\
\hline Test for flavonoids & - & + & + & + & + & + \\
\hline Test for amino acids & + & - & - & + & - & + \\
\hline Test for steroids & + & + & + & + & - & + \\
\hline Test for fat and oil & - & + & + & + & - & + \\
\hline Test for mucilage & - & - & - & - & - & - \\
\hline
\end{tabular}

DCM: Dichloromethane

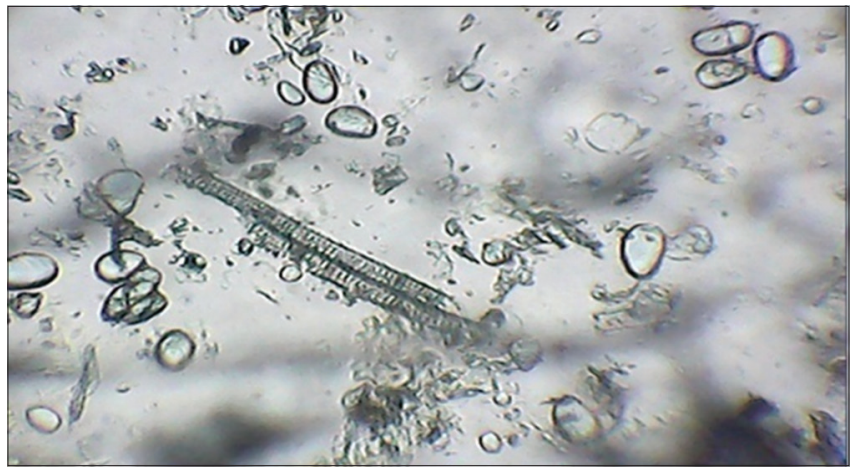

Fig. 14: Isolated fiber

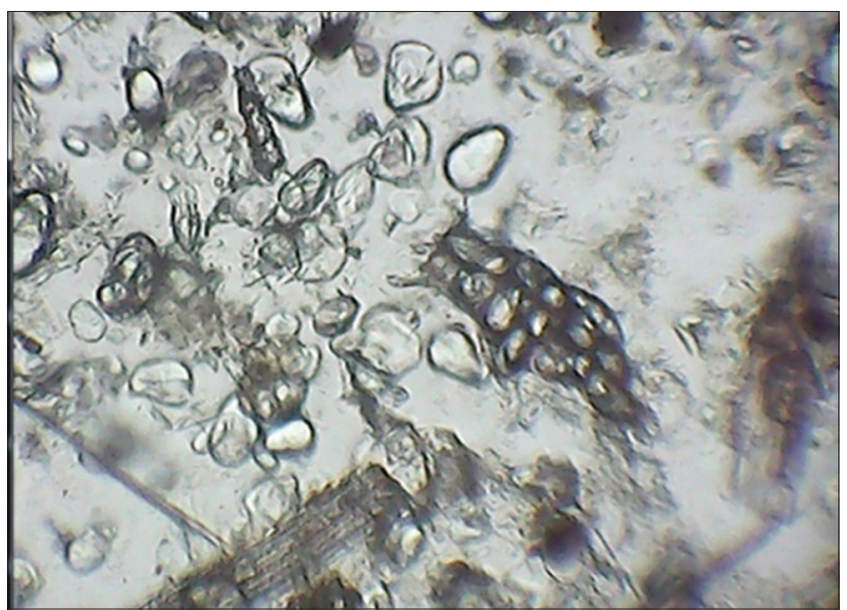

Fig. 15: Isolated parenchyma

analysis observed in visible, short, and long ultraviolet is depicted in Table 2 (Figs. 11-17).

\section{Physiochemical parameters}

The physiochemical parameters such as total ash value were found to be $7.4 \%$, water soluble ash $2.85 \%$, acid insoluble ash $1.85 \%$, and moisture content \% LOD is $8 \%$. The extractive values are mainly useful for the determination of the exhausted or adulterated drug. Water soluble extractive values and alcohol soluble extractive values were found to be $13.4 \%$ and $10.24 \% \mathrm{w} / \mathrm{w}$ respectively.

\section{Preliminary phytochemical examination}

Preliminary phytochemical investigation of rhizome extracts as shown in Table 3.

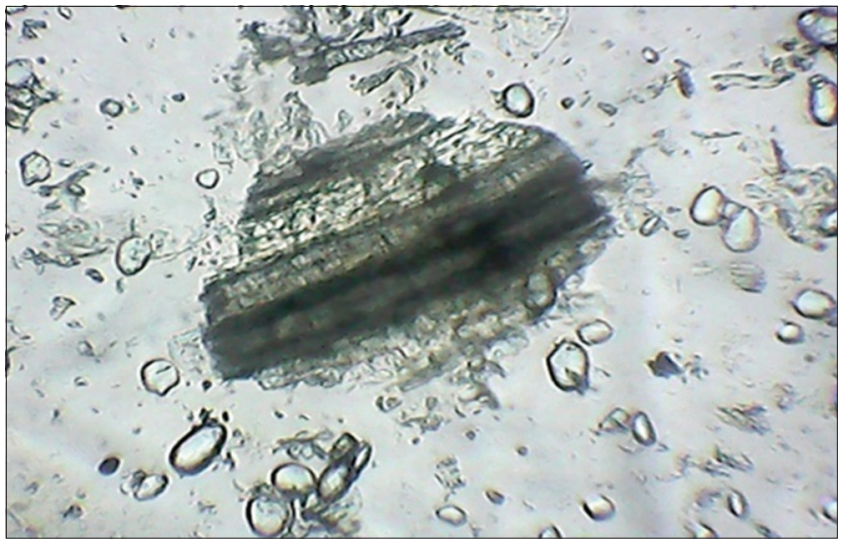

Fig. 16: Vessels

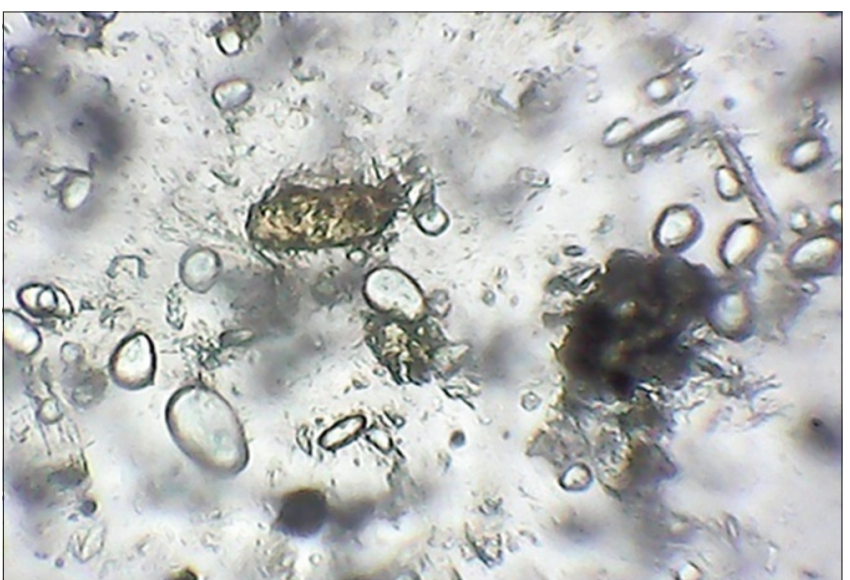

Fig. 17: Yellow colored oil globules

Thin-layer chromatographic analysis of extract

TLC analysis of extracts gives the idea about the presence of chemical compounds. Fig. 18 shows TLC of DCM extract and Fig. 19 shows TLC of alcoholic extract. The spot color and Rf values are informed in Table 4.

\section{CONCLUSION}

The plant $Z$. cassumunar Roxb. find application in Ayurvedic and other traditional system of medicine and have some important characteristic features in rhizomes in order to identifying the plant material. The macroscopic and microscopic characters reveal the presence of yellow colour inside the rhizomes, which is important diagnostic characters that help in identification of plant material. The physicochemical 
Table 4: Rf values of DCM extract and alcoholic extract of Zingiber cassumunar Roxb

\begin{tabular}{lllll}
\hline Extract name & Rf & Values & Spot color & Mobile phase \\
\hline DCM extract & Rfa & 0.9 & Light yellow & Chloroform:DCM (5.4:11.2) \\
& Rfb & 0.7 & Reddish yellow & \\
Rfc & 0.43 & Brownish & \\
Alcoholic extract & Rfd & 0.18 & Reddish brown & Toluene:ethylacetate:methanol:formic acid (6:6:0.4:1.6) \\
& Rfa & 0.73 & Yellowish brown & \\
\hline
\end{tabular}

DCM: Dichloromethane

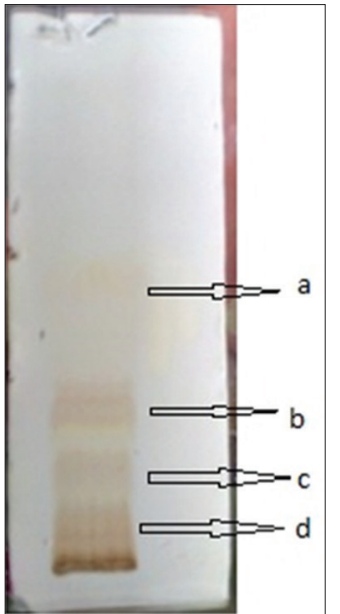

Fig.18: DCM Extract

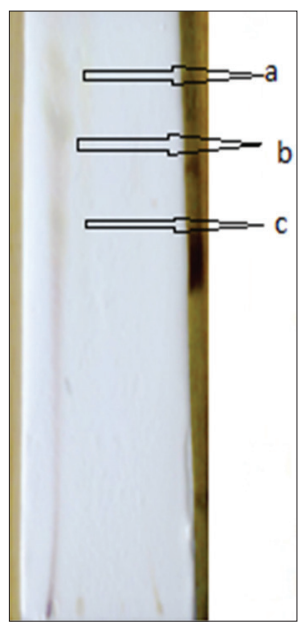

Fig. 19: Alcoholic Extract.

studies are carried out on herbal plant powder sample to establish appropriate data that may be utilized for identification and establish the purity, standard of plant sample, and those supplied in powder form [19]. The estimation of ash value commonly applied parameter for the identification, which establishes the quality and the purity of the drug. Ash value can also detect the nature of the material added to the drug for the purpose of adulteration [20]. The moisture content of the material can be identified by percentage weight of LOD. The phytochemical screening of the drug is very important to identify the different phytoconstituents present in plant materials such as steroids, terpenoids, and flavonoids. It is a very important in the process of standardization and quality control because the constituent vary from plant to plant and also in different samples of the same species depending on various atmospheric factors and storage conditions. TLC method has emerged as an important tool for the qualitative and quantitative phytochemical analysis of herbal drugs. TLC mobile phase detection and separation of active constituents has found a variety of analytical uses in the Pharmaceutical industries. Chromatographic analysis is the first step toward understanding the nature of active principles and their detailed phytochemistry [21]. The reported pharmacognostic parameters can be considered as distinctive enough for authentification of this drug in herbal industry and can be included as microscopic standards in Indian herbal pharmacopoeia [22].

\section{ACKNOWLEDGEMENT}

The authors would like to acknowledge the Principal Dr. C S. Magdum sir and Vice Principal Dr. S K. Mohite sir of Rajarambapu College of Pharmacy, Kasegaon for providing facility to conduct the research work.

\section{REFERENCES}

1. Mukherjee P. Quality Control of Herbal Drugs - An Approach to Evaluations of Botanicals. $5^{\text {th }}$ ed. New Delhi: Business Horizons; 2005. p. 2 .

2. Vogel GH. Drug Discovery and Evaluation: Pharmacological Assays. Cham: Springer; 2003. p. 202.

3. Pongprayoon U, Soontornsaratune P, Jarikasem S, Sematong T, Wasuwat S, Claeson P. Topical antiinflammatory activity of the major lipophilic constituents of the rhizome of Zingiber cassumunar. Part I: The essential oil. Phytomedicine 1997;3:319-22.

4. Tewtrakul S, Subhadhirasakul S. Anti-allergic activity of some selected plants in the Zingiberaceae family. J Ethnopharmacol 2007;109:535-8.

5. Lu Y, Sun C, Wang Y, Pan Y. Preparative isolation and purification of two phenylbutenoids from the rhizomes of Zingiber cassumunar by upright counter-current chromatography. J Chromatogr A 2005;1089(12):258-62.

6. Khandelwal KR. Practical Pharmacognosy. $16^{\text {th }}$ ed. Pune: Nirali Publication; 2010. p. 149-61.

7. Ahmed RS, Sharma SB. Biochemical studies on combined effects of garlic (Allium sativum Linn) and ginger (Zingiber officinale Rosc) in albino rats. Indian J Exp Biol 1997;35:841-3.

8. Grzanna R, Lindmark L, Frondoza CG. Ginger - An herbal medicinal product with broad anti-inflammatory actions. J Med Food 2005;8:125-32.

9. Prakash RO, Kumar RK, Rabinarayan A, Kumar MS. Pharmacognostical and phytochemical studies of Zingiber Zerumbet (L.) Sm. Rhizome. Int J Res Ayurveda Pharm 2011;2(3):698-703.

10. Varier PS. Indian Medicinal Plants - A Compendium of 500 Species. Vol. 1. Kottakkal-India: Orient Longman Publishing House; 2002. p. 146.

11. Nancy P, Ashlesha V. Pharmacognostic and phytochemical studies of cassia absus seed extracts. Int J Pharm Pharm Sci 2016;8(1):325-32.

12. Government of India. The Ayurvedic Pharmacopoeia of India. $1^{\text {st }}$ ed. New Delhi: Ministry of Health and Family Welfare, Department of Indian Systems of Medicines and Homeopathy; 2009. p. 242-4

13. Kokate CK. Practical Pharmacognosy. $4^{\text {th }}$ ed. New Delhi: Vallabh Prakashan; 2010. p. 17-26.

14. Kokoski CJ, Kokoski RJ, Slama FJ. Fluorescence of powdered vegetable drugs under ultraviolet radiation. J Am Pharm Assoc Am Pharm Assoc 1958;47:715-7.

15. WHO. Quality Control Methods for Medicinal Plant Material. Geneva: WHO; 1992. p. 22-34

16. Government of India. Indian Pharmacopeia. $4^{\text {th }}$ ed. New Delhi: Ministry of Health and Welfare, Controller of Publications; 2007. p. A53-4

17. Koparde AA, Magdum CS. Conventional and microwave assisted extraction of Eulophia ochreta Lindl and Zingiber cassumunar Roxb: 
An comparitive account. Res J Pharm Tech 2014;7(7):746-8.

18. Khadabadi SS, Deore SL, Baviskar BA. Experimental Phytopharmacognosy: A Comprehensive Guide. $1^{\text {st }}$ ed., Annx-2. India: Nirali Prakashan; 2011. A2.1.

19. Kumar S, Kumar V, Prakash OM. Pharmacognostic study and antiinflammatory activity of Callistemon lanceolatus leaf. Asian Pac J Trop Biomed 2011;1:177-81.

20. Jain S, Koka S, Gupta A, Barik R, Malviya N. Standardization of
"Chopchiniyadi Churna": An ayurvedic polyherbal formulation. Phcog J 2010;2(5):60-4.

21. Kumar D, Gupta J, Kumar S, Arya R, Kumar T, Gupta A. Pharmacognostic evaluation of Cayratia trifolia (Linn.) leaf. Asian Pac J Trop Biomed 2012;2:6-10.

22. Netala S, Penmetsa R, Nakka S, Polisetty BL. Pharmacognostic study of Callistemon Citrinus L. bark. Int J Pharm Pharm Sci 2015;7(1):427-30. 